\title{
DETERMINANTS OF CUSTOMER'S SATISFACTION IN THE FAST FOOD INDUSTRY IN ANAMBRA STATE OF NIGERIA
}

\author{
Chendo, Nkoli Augustina \\ Chukwuemeka Odumegwu Ojukwu University Uli, \\ Nigeria
}

\begin{abstract}
The study examined the determinants of customers' satisfaction in the fast food industry in Anambra State of Nigeria. The study utilized 149 usable copies of the questionnaire for analysis. Cross-sectional survey method was used while primary source of data was used. Data collected were analyzed while the hypotheses formulated were tested using OLS regression analysis. The result revealed that physical environment, price and physical quality have positive significant effect on customer's satisfaction in the fast food industry whereas service quality has positive insignificant influence on customer's satisfaction in the fast food industry in Anambra State of Nigeria. Based on the findings, the study recommends that managers of fast food industry should pay attention to these variables in their decisions when making marketing strategies since they play a significant role in the marketing field.
\end{abstract}

KEY WORDS: customer's satisfaction, service quality, physical environment, price, physical quality.

\section{INTRODUCTION}

\section{Background to the Study}

Every business needs repeat customers to foster and to increase profit. This behaviour of customer will remain loyal and completely satisfied until they received services which the company promises to deliver (Hernon, Nitecki and Altman, 1999). Also, management should additional highlight on enhanced policies of customer satisfaction in connotation of service quality (Dominici and Guzzo, 2010). Customer's satisfaction is largely dependent on service quality (Bell, Gilbert and Lockwood, 1997).

Quality matters a lot but when we contemplate service quality of food, as it is a vitalportion of a product. Establishments cannot attain their objectives without drawing adequate satisfied customers. Service quality distinguishes itself between other services by giving fulfilment to their customer.

It means customer satisfaction is the crucial to victory of firms which observes service quality as the highest success influence (Rana, Lodhi, Butt and
Dar, 2017). In Nigeria, consumers' way of life has enormously aided the fast food industry to developed and enlarge in the recent time. Other motives like increasing number of nuclear relatives, revelation to western cuisine and global media, rising number of working women - have had a considerable effect on the eating out trends and growth of the fast food business.

The business specialists contemplate that the middle class early population, with great disposable revenue, will spend more on eating out at bound fast food passages. The request for ready-to-eat wrapped food is also likely to record robust development in the country. In today's competitive world, Service Quality has become one of the greatest strategic tools for computing customer satisfaction.

Customer satisfaction is truly how customer assesses the on-going performance (Gustafsson, Johnson and Roos, 2005). The word fast food is use for the food which can be prepared and served quickly than any other meal, minimum preparation time is considered for fast food, generally this term refers to food sale in restaurants and stores with low 
time preparation and served to customers in form of packaged for take away /takeout (Anifowose \& Olaleye, 2016). This study was conduct to ascertain the factors for customer satisfaction. The sense of pleasure and dissatisfaction is known as fulfilment.

If the product was not satisfied, person feelings will be displeased, and if product satisfied, person feelings after the use will be fulfilled.

\section{Statement of the Problem}

Fast Food Restaurant in recent time has tried to introduce various strategies and promotional tools to help sustain their sales volume, market share and profitability, these are employed to ensure continuous increase in customer patronage since the Fast food industry is not exempted from the fierce competition that is follows sophisticated consumer taste as regards to service quality, physical environment and product prices (Anifowose \& Olaleye, 2016).

Anambra State is one of the states in Nigeria that have several Fast Food Restaurants. The study focused on Fast Food confectionaries in Anambra State using purposive sampling to select the target respondents. This selection of eateries that participated in this study was based on their reputation and most importantly their standards. Five outlets were selected and they include; Crunchies, Mr.Biggs, Emelek, Kamba Kitchen, Twine Tasty, Orenge Fast Food. This valuation was carried out in the designated Fast Food Restaurants to know the determinants of customer satisfaction and to determine if customer satisfaction on service quality, physical environment and price are the major motive for benefaction in the selected Fast Food Restaurants.

Numerous studies have been carried out in different countries of the world on Fast Food Restaurants from different dimensions (Anifowose \& Olaleye 2016; Ukessay, 2013; Carew, 2010; Park, 2004; Lowenstein, 1995) and each summarizing diverse views of customer satisfaction, service quality, physical environment and product price; and Nigeria is not an exclusion from this study.

In their study customer satisfaction on service quality has been measured by different models most especially SERVQUAL model to determine customer satisfaction on service quality, customer loyalty and retention decision. Despite numerous studies in Nigeria, factors of customer satisfaction and its effect on customers' patronage to the finest of my knowledge as not been focused on in Anambra State. Based on this motives this research was carried out to determine the determinants of customers' satisfaction in the fast food industry in Anambra State of Nigeria.

\section{Objectives of the Study}

The main objective of the study is to investigate the determinants of customers' satisfaction in the fast food industry in Anambra State of Nigeria. The specific objectives are to; determine the effect of service quality on customers' satisfaction in the fast food industry in Anambra State of Nigeria.

Determine the effect of physical environment on customers' satisfaction in the fast food industry in Anambra State of Nigeria.

Examine the effect of product price on customers' satisfaction in the fast food industry in Anambra State of Nigeria.

Examine the effect of product quality on customers' satisfaction in the fast food industry in Anambra State of Nigeria.

\section{Research Questions}

1. To what extent does service quality affect customers' satisfaction in the fast food industry in Anambra State of Nigeria?

2. How does physical environment affect customers' satisfaction in the fast food industry in Anambra State of Nigeria?

3. To what extent does product price affect customers' satisfaction in the fast food industry in Anambra State of Nigeria.

4. How does product quality affect customers' satisfaction in the fast food industry in Anambra State of Nigeria.

\section{Hypotheses of the Study}

Service quality does not significantly affect customers' satisfaction in the fast food industry in Anambra State of Nigeria.

Physical environmentdoes not have any significant effect on customers' satisfaction in the fast food industry in Anambra State of Nigeria. Price does not have any significant effect on customers' satisfaction in the fast food industry in Anambra State of Nigeria.

Product quality does not significantly affect customers' satisfaction in the fast food industry in Anambra State of Nigeria.

\section{REVIEW OF RELATED LITERATURE Conceptual Framework}

Customer satisfaction Customer satisfaction is the after purchase judgment or evaluation of a product or a service. It is also frequently described as the extent to which the chosen product meets or exceeds consumer expectations (Oliver, 1980).

Zairi (2000) stated that the sense of wish and anticipation realization is known as fulfilment. If the product will not satisfied customer feelings they will be dissatisfied, and if product pleased them after the use customer will be fulfilled and become loyal to that product or brand.

In other words customer satisfaction is goods or services which achieve the customer anticipation in terms of quality and service for which he paid. According to Lin \& Wu (2011), customer satisfaction in the advertising context is an important that leads to long term customer retention because the dissatisfied customers has the choice to change brands or a fulfilled customers will probably talk to others about their good experiences; and this implies that customers satisfaction play an enormous role in the existence of the industry. 
Customer satisfaction in services has also been defined as the proportion at which service offer in meets or exceeds the customer's expectations (Kumar, 2012; Lombard, 2009; Santouridis and Trivellas, 2010). Hui and Zheng (2010) also refer satisfaction as an evaluative decision of an exact business resulting from professed quality. Customer's satisfaction is the customer's assessment of goods and services in term of whether it is conferring to the customer's needs and wants or customers displeased with the product services or the displeased with the performance of the products and not according to anticipation of customers and sometime customers more pleased if products performance is beyond with their prospects (Kotler, 2012).

Customer satisfaction becomes the greatest significant part in the commercial arena because if your customers are pleased then it will offer the sustainability of your business operations (Deng et al., 2009). It has also become a key intermediary objective in service operations as a result of the advantage it brings to firms (Ranaweera and Prabhu, 2003).

Barkema and Drabenstott (1995) stated that today's consumer who demands anever-widening variety of healthy and conveniently prepared food products, is driving the changes in food markets all over the globe. Customers generally evaluate service quality before and after their consumption. According to Zeithaml et al (1993), consumers appraise services and products through two processes; namely, pre-purchase or search qualities are features that consumers look out for before buying and are those that they can see, feel or touch.

On the other hand, skilled potentials are postpurchase features that customers evaluate during the post-purchase period. Customers cannot evaluate these types because they do not have the required skills, expertise and knowledge to carry out the evaluation. To that effect, customers place a great value on the image and reputation of the service before purchasing.

\section{Service Quality}

Quality is standard of something which consumer measure against the other different benchmark; quality can be measured by grading, merit, attributes etc. to the products or services (Takeuchi, 1983). Service quality is assessed when the out customer liken his/her insight and anticipation of service delivery (Gronroos, 1984).

Many academics most often use service quality to measure customer satisfaction (Zeithaml, 1985); for evaluating and assessing numerous scopes of service quality is the tool accepted as standard (Kurniawan, 2010). According to Zeithaml (1985), it is a scale with numerous items good validity and reliability; many investigators use this tool to comprehend and discovery the service anticipation and consumer's insight for refining the service quality. The anticipation of a customer is a vital influence.

The extra service quality is near to customer anticipation extra fulfilment and vice versa (Ayse Ozfer Ozcelik, 1988). Service can be referred in various ways depending on which area the term is being used. Kotler and Keller, 2009 refers service as "any intangible act or performance that one party offers to another that does not result in the ownership of anything".

In other words service can also be referred as an intangible offer by one party to another in interchange of money for pleasure (Jenet 2011). In service advertising works, "service quality is generally referred as the overall valuation of a service by the customers, (Jenet 2011) or the degree to which a service meets customer's needs or prospects".

Service quality is normally noted as a critical precondition and factor of competitiveness for establishing and supporting filling associations with customers. Service quality has been viewed more important than product quality (Ghobadian, Speller and Jones, 1994). Schlesinger and Heskett (1991) defined the desired service quality cycle as repeatedbonding between the customers' satisfaction and service quality and their further impact on behavioral intentions. Previous study suggests that service quality is a vital gauge of customer satisfaction (Spreng and Machoy, 1996).

Attention to service quality can make an institute diverse from other establishments and gain a permanent competitive benefit (Boshoff and Gray, 2004). Service quality has been measured by several models but this research will consider SERVQUAL model. According to Parasuraman et al., (1988), there are some dimensions of service quality through which you can measure the service quality known as SERVQUAL model such as the - Credibility which is the worth and value that a customer offers to your service. - Reliability is the fulfilment of the company's assurance of their service.

- Responsiveness is assessment of interest in answering the problems of the customers by business that how abruptly a business replies to his customers. - Empathy to ability the comprehend customer sense and resolve the customer problems. - Tangible is the physical presence of employees to share and offer the exact services.

\section{Physical Environment}

The variable which also influences the customer satisfaction is the physical environment of the restaurant because in Nigeria there is developing of the concept of branded and well-furnished restaurants due to the growing literacy rate and the situation of the economy. According to the Lim (2010) the atmosphere of the restaurant affects the customer satisfaction and these includemusic, furniture arrangement, decoration among other things creates the optimistic image of the restaurant in the mind of the customers. 
Lim (2010) was of the opinion that customer's ultimate satisfaction may have important influence on atmosphere. Physical surroundings are obliging to create positive or negative image in the memory of customer and to affect their behavior towards their offering. Physical atmosphere of the restaurants have an important influences on the customers satisfaction.

Lightning, interior decor, frangance, music and different other atmospheric factors influences customer satisfaction to a great extent. The descriptions in this category concentrated on the facilities. Marketing literature, especially retailing, has emphasized the significance of environment/atmospherics in consumer behaviour and response (Berry, 2000; Bitner, 1992). The associations included many aspects such as lighting, the arrangement of furniture, noise levels, temperatures, and cleanliness of the restaurant.

Specifically, the comments included; "the bathrooms have wet floors," "always have loud music," "extremely squeezed and stuffy" (Njite, 2005).

\section{Price}

Consumers usually do not know the exact cost of the offering, but have an idea whether aoffering is more expensiveor cheaper than its competitor (Frazen and Bouwman, 2001). The perceived relative product price is important because consumers often base the judgement of a product on it.

Consumers groupvarious products into several price ranges, from "very cheap" to "very expensive." The classification of a product into one of the price rangesaffects the consideration set as well as the possible intentions to transact ( $\mathrm{Njite}$, 2005). In Nigeria, price is the key element in the customer satisfactions in Fast Food Restaurants because most of the customers on the price of the brand then further purchase it according to the diverse study price of any product can form and can be down the normal of the brand (Turel et al. 2006).

According to Gustafsson et al. (2005), product price plays a significant role in the customer satisfaction because the fixed price of the product directly or indirectlyinfluence the customer's decision making process, so if it is affordable then customers will be more satisfied with it and will be willing to purchase the repeatedly.

Offering a product at a fair price enhances customer satisfaction since the customers will not feel cheated because price is among the elements which consumers critically consider before making purchases. So for the customer satisfaction the service provider must focus on the charges of the brand which they are providing to the customers. Bell, Gilbert and Lockwood (1997) described price to value ratio as another critical factor in defining customer satisfaction.

Johns and Howard (1998) opnies that price to value ratio is an important element in determining customer satisfaction. Soriano (2002) showed that there is a positive relationship between the price to value, repeat purchase behaviour and customer loyalty. There is a positive and significant bonding between the perceived value and customer satisfaction.The perceived value is defined as the perceived level of quality compared to the price paid (Fornell, Johnson, Anderson, Cha and Bryant, 1996).

Hence, in support of the literature review price attached to a product is a key determinant factor to customer satisfaction and therefore used to ground the third hypothesis of this research paper. Skindaras (2009) stated that there are millions of products in this world various prices tags. Pricing a product is difficult thing to do and goes a long way in determining how successful a product will be in the competitive marketing environment. Prices are set according to the value of the product.

Han (2009) states that one of the most flexible elements that changed quickly is price. In the literature of Khan (2011) marketing the most important factor indicated for customer satisfaction is price, because most of the customers estimate the value of the product or obtained service through price.

\section{Theoretical Framework}

Disconfirmation Theory Oliver (1980) as cited in Anifowose \& Olaleye (2016) was the first to propose and developed the expectancy disconfirmation theory. Disconfirmation theory asserts that satisfaction is related to the size and direction of the disconfirmation experience that happens as a result of comparing service performance against expectations. In several studies such as Oliver and Desarbo (1988); Satari (2007), disconfirmation theory has been subjected to tested and confirmed.

In the meta-analysis, Szymanski and Henard (2004) found that disconfirmation perception is the best predictor of customer satisfaction; while Ekinci et al (2004) cites Oliver's updated definition on the disconfirmation theory, which states that Satisfaction is the guest's fulfilment experience. It is a judgment that a guest has on a product or service feature, or the product or service itself, provided (or is providing) a pleasurable level of consumption-related fulfilment, including levels of under- or over fulfilment'.

According to Agbemabiese, Patrick and Adu (2015), negative disconfirmation occurs when perceived service or product value is below expectation while positive disconfirmation occurs when perceived service or product is better than expected. They were of the opinion that customer dissatisfaction is caused by negative disconfirmation of consumer expectations and customer satisfaction occurs by confirmation or positive disconfirmation of consumer expectations (Anifowose \& Olaleye, 2016).

\section{Empirical Review}

Rana, Lodhi, Butt and Dar (2017) examined how determinants of customer satisfaction are affecting the brand image and behavioural intention 
in fast food industry of Pakistan, the relationship between customer satisfaction and behavioural intention in the fast food chains were investigated. A survey was conducted in three major cities of Pakistan as Sahiwal, Lahore, and Gujranwala. Data were generated from fast food consumers and the target sample size was 166 respondents arrived at by convenience sampling technique of non-probability sampling. PLS-SEM was used to interpret the results of the study. The finding revealed that positive customer satisfaction leads to positive behavioural intention and healthy brand image in the minds of customers. The results will lead the managers of the industry to prioritize the focus on various antecedents of satisfaction of customer especially food quality, service quality and price value ratio.

Manjunath and Reginald (2016) examined the key success factors for fast food industry in region of Mysore District. The study considered two variables, i.e. independent and dependent variables.Customer satisfaction in fast food industry showing dependency on service quality, Product Quality, Physical Design, Price, Customer satisfaction, Physical Environment, Taste and Promotion. Different statistical tools were used to analyze the primary data and they include Correlation coefficients, multiple linear regressions. ANOVA, and Regression Co-efficient. Findings of the study showed that service quality and physical design are the key elementsthat enhances satisfaction in fast food industry in Mysore District.

Anifowose and Olaleye (2016) investigated the assessment of customers' satisfaction on service quality of fast food restaurant (FFR) in Akure Metropolis Ondo state, Nigeria. The analysis showcased how consumers perceive service quality through SERVQUAL model that poor or low and unsatisfied services were rendered to the numerous customers by the selected FFRs management in this study area. Despite with all these poor service offered, customers are still patronizing the selected FFRs due to its location and food quality.

Measuring service quality can help management provide reliable data that can be used to monitor and maintain improved service quality. In conclusion, using the SERVQUAL model to assess service quality enables management to better understand the various dimensions and how they affect service quality and customer satisfaction. This will help them to identify their strengths and weaknesses and thereby make necessary improvements.

Adiele, Miebaka and Ezirim (2015) examined the impact of physical evidence on customer patronage of quoted Banks in south-south zone of Nigeria. 14 quoted Banks at the Nigeria Stock Exchange Market were used for the study. The research considered firm level of analysis and top managers unit of analysis. Customers of the chosen banks were also examined. This resulted to, 42 managers and 7 customers which were randomly selected to stand as the sample size. Descriptively, the study variables were presented and inferentially, the Spearman Rank Correlation Coefficient was used in testing the formulated hypotheses. They employed the Pearson Partial Correlation to ascertain the extent to which the organizational factors mediate the relationship between physical evidence and customer patronage. The result of their analysis showed that there is a strong positive and significant correlation between physical evidence and customer patronage.The study specifically revealed that efficient design of work place ambience; physical architecture and signs has significant positive effect on Profit margin, sales volume, and customerretention. It was further found that organization size and information technology capability strongly mediated the relationship between the predictor and criterion variable.The study therefore concluded that physical evidence significantly affects customer patronage.

Dipeolu, Adewuyi, Ayinla and Bakare (2014) assessed the factors affecting customer satisfaction and its effect on repurchase intention at selected Fast Food Restaurants (FFRs) in Ibadan metropolis, Nigeria. Primary data were obtained by administering structured questionnaire on a crosssection of 147 Customers of Fast Food Restaurants (CFFRs) that patronizes FFRs. Multistage random sampling technique was employed to select seven (7) FFRs from the metropolis, and the study concludes that customer satisfaction significantly enhances repurchase intention and this is closely related to the customers' perception of tangibility, responsiveness, assurance and empathy dimensions of service quality.

Sabir, Ghafoor, Hafeez, Akhtar and Rehman (2014) examined the factors affecting customer's satisfaction in restaurants industry in Pakistan. The study tried to examine, compare and evaluate the determinants of the customer's satisfaction in fast food industry. Quality service, price, environment were used as an independent variables and customers satisfaction use as dependent variable. Random sampling technique was used for data collection through a questionnaire survey and the sample size for this study was 100. Data were analysed with the help correlation and, multiple regressions. The study revealed that there is positive and significance relationship between these variables such as price, quality in service and the environment of the restaurants and the customer's satisfaction.

Adiele and Opara (2014) examine the impact of corporate identity on customer patronage of quoted Banks in south-south zone of Nigeria. The study population was 14 quoted Banks, and their unit for data generation was the top level managers of the 14 quoted banks and customers. Forty two (42) managers on the ratio of 3 managers per bank constituted their respondents for the study. The Spearman's Rank Correlation Coefficient (SPRCC) statistical tool was used in testing the stated 
hypotheses. The result of the analysis showed that there is a positive and significant correlation between corporate identity and customer patronage. The study showed that signs and symbols significantly affect sales volume, profit margin, and customer retention. Khan, Hussain and Yaqoob (2013)examined the determinants of Customer Satisfaction in Fast Food Industry in Peshawar, Pakistan. The failure or success of an eatery is based on some factors like Service quality, sales promotion, brand image, customer expectations, physical ambience, product price, and Taste of the product. To find which of these factors has the most significant influence on consumer satisfaction, four fast food restaurants customers were targeted randomly. The four eateries were KFC, CHIEF, ARBAIN CHICK, and PIZZA HUT. The data collected from the customers of these eateries. Total number of customers who were targeted was 120 . From each eateries 30 customers were targeted on availability basis. On the basis of their responses multiple regression and correlation test was used to analyze the generated data.Findings of the study revealed that service quality and brand are the key factors for satisfaction in fast food subsetor in Peshawar Pakistan.

Janet (2011) examined the relationship between customer satisfaction and service quality in Umea. The study applied SERVQUAL model; and revealed that customers' perceptions of service quality offered by the surved grocery stores did not meet their expectations (i.e. all gaps scores, the dimensions showed negative indexes). Dimensions that reported larger mean gaps were reliability ($1,0901)$, responsiveness $(-1,0033)$ and assurance ($0,8675)$ while smaller mean gaps obtained were products $(-0,4834)$, tangibles $(-0,6275)$ and empathy $(-0,6874)$. These values reveal that the customer's perception of performance in grocery stores is below the expected level of service quality which means that customer satisfaction is low.

Ahmad Al-Tit (2005) investigated the relationships between service, food quality,customer retention and customer satisfaction in a sub-sector of eateries in Jordan. The study found a significant positive relationship between service quality, retention and customer satisfaction.

\section{METHODOLOGY}

This section focused on Research design, Population, Sample size and Sampling techniques. The study adopted cross-sectional survey design to generate data needed to get accurate information for proper decision-making. The population of the study comprises the fast food restaurants in Anambra State of Nigeria. This sampling technique was based on the firm'simage and most importantly the standards of their operations.

The target population is about 298 and the study used $50 \%$ to settle for 149 respondents. The questionnaire was used to obtain and gather information to analyse and compare the determinants of customers' satisfaction in the fast food sub-sector in Anambra State of Nigeria. The questionnaires were administered to the respondents through drop and pick method.

This method was selected because it doesn't inconvenience the respondents since they could answer the questions during their free time. To ensure fairness on the sampling method, respondents were given the opportunity to be evenly selected by picking a card through a lucky dip. Only those who picked (yes) through a simple random lucky dip were given copies of the questionnaire to fill and submit.

Prior to the main study, the instrument was validated by two research experts. Their corrections and suggestions coupled with the modifications ensured the soundness, accuracy and as well, that the instrument measured what it is supposed to measure. The reliability for this study was established through test retest method.

Questionnaire which was developed from the literature was structured to have three sections; A, B \& C. Section A captured the demographic characteristics as well as general information about the respondents. Section B focuses on determinants variables while Section C measured customers' satisfaction.

Likert five point scale style of structured questionnaire was adopted; thus; strongly disagree $(\mathrm{SD})=1$, Disagree $(\mathrm{D})=2$, Undecided $(\mathrm{UND})=3$, Agree $(A)=4$ and strongly agree $(S A)=5$. Simple linear regression analysis was used to test the four formulated hypotheses at 0.05 significant levels. The Decision rule for rejecting or accepting null hypothesis is thus; if the $\mathrm{P}$-value is greater than $5 \%$ (0.05) significant level used, null hypothesis should be accepted. Otherwise, reject null hypothesis if the $\mathrm{P}$-value is less than 0.05 , the stipulated significant level.

\section{Model Specification \& Operationalization of the Variables}

The researcher adopts Rio, Vazquez and Iglesias (2001) model and modified it as follows; The model the researcher used in the study took the form below: $\mathrm{Y}=\mathrm{f}\left(\mathrm{X}_{1}, \mathrm{X}_{2}, \mathrm{X}_{3}, \mathrm{X}_{4}, \mathrm{e}\right) \ldots \ldots \ldots \ldots \ldots \ldots \ldots \ldots . . . \mathrm{I}$ $Y=a_{0}+\beta_{1} X_{1}+\beta_{2} X_{2}+\beta_{3} X_{3}+\beta_{4} X_{4}+e \ldots$.

\section{Where:}

$\mathrm{Y}=$ customers' satisfaction; $\mathrm{a}=$ Constant Term; $\beta=$ Beta Coefficient -This measures how many standard deviations and dependent variable will change, per standard deviation increase in the independent variable. $X_{1}=$ service quality; $X_{2}=$ physical environment; $\mathrm{X}_{3}=$ price; $\mathrm{X}_{4}=$ physical quality $\mathrm{e}=$ Error term. The 0.05 level of significance was used as a reference in rejecting or accepting the hypothesis.

From the above, we can state the following:

$\mathrm{CS}=\mathrm{a}+\beta_{1} \mathrm{SQ}+\beta_{2} \mathrm{PE}+\beta_{3} \mathrm{PR}+\beta_{3} \mathrm{PQ}+\mathrm{e} \ldots \ldots$

$\mathrm{CS}=$ customers' satisfaction

$\mathrm{SQ}=$ service quality

$\mathrm{PE}=$ physical environment

$\mathrm{PR}=$ price 
$\mathrm{PQ}=$ product quality

\section{DATA PRESENTATION AND ANALYSIS}

The data generated from the 149 usable copies of the questionnaire returned (100\% response rate) out of149 copies distributed to respondents were presented and analysed.
The demographic characteristics of the respondents as well as the descriptive statistics of the variables were presented while Pearson correlation was used to show the relationships among the variables. Simple regression analysis was used to determine the prediction and statistical influence of the independent variables on the dependent variable.

\begin{tabular}{llllll}
\multicolumn{5}{c}{ Table 4.1: Descriptive Statistics of the Variables } \\
\hline VARIABLES & CS & SQ & PE & PR & PQ \\
\hline Mean & 29.80000 & 29.80000 & 29.80000 & 29.80000 & 29.80000 \\
Median & 23.00000 & 23.00000 & 26.00000 & 23.00000 & 25.00000 \\
Maximum & 90.00000 & 90.00000 & 90.00000 & 90.00000 & 90.00000 \\
Minimum & 5.000000 & 5.000000 & 5.000000 & 8.000000 & 5.000000 \\
Std. Dev. & 22.60770 & 22.42284 & 22.34617 & 22.54725 & 22.50465 \\
Skewness & 0.978317 & 0.980532 & 0.870527 & 0.946370 & 0.943595 \\
Kurtosis & 2.848870 & 2.789905 & 2.623248 & 2.725087 & 2.769645 \\
Jarque-Bera & 12.03519 & 12.15598 & 9.916279 & 11.43138 & 11.29547 \\
Probability & 0.002436 & 0.002293 & 0.007026 & 0.003294 & 0.003525 \\
Sum & 2235.000 & 2235.000 & 2235.000 & 2235.000 & 2235.000 \\
Sum Sq. Dev. & 37822.00 & 37206.00 & 36952.00 & 37620.00 & 37478.00 \\
Observations & 75 & 75 & 75 & 75 & 75
\end{tabular}

Source: E-view Computations Output, 2019

Table 4.1 above reveal the mean scores for service quality, physical environment, price and product quality as well as customers' satisfaction. They are 29.80000 for each variable. The minimum score by the respondents under customers' satisfaction (CS) responses was 5.000000 whereas the maximum score made by the respondents was 90.00000. The minimum score by the respondents under service quality (SQ) responses was 5.000000 while the maximum score was 90.00000. The minimum score by the respondents under physical environment (PE) responses was 5.000000 while the maximum score was 90.00000 .

The minimum score by the respondents under price (PR) responses was 8.000000 while the maximum score was 90.00000 . The minimum score by the respondents under product quality (PQ) responses was 5.000000 while the maximum score was 90.00000. Moreover, the standard deviation for customers' satisfaction, service quality, physical environment, price and product quality are; $22.60770,22.42284,22.34617,22.54725$ and 22.50465 respectively.

The large differences between the maximum and minimum value show that the variables portrayed significant variations in terms of magnitude, thus suggesting varying estimation levels.

\begin{tabular}{llllll}
\hline & \multicolumn{5}{c}{ Table 4.2: Pearson Correlation Matrix } \\
\hline VARIABLES & CS & SQ & PE & PR & PQ \\
\hline CS & 1.000000 & 0.931230 & 0.933971 & 0.928478 & 0.933077 \\
SQ & 0.931230 & 1.000000 & 0.948224 & 0.940249 & 0.940249 \\
PE & 0.933971 & 0.948224 & 1.000000 & 0.922528 & 0.929675 \\
PR & 0.928478 & 0.940249 & 0.922528 & 1.000000 & 0.939334 \\
PQ & 0.933077 & 0.955820 & 0.929675 & 0.939334 & 1.000000 \\
\hline
\end{tabular}

Source: E-view Computations Output, 2019

The correlation matrix is to check for multicolinearity and to explore the association between each explanatory variable and the dependent variable. The findings from the correlation matrix table 4.2 above show that customers' satisfaction (CS) has a positive association with service quality (0.931230), physical environment $(0.933971)$, price (0.928478) and product quality (0.933077). Service quality has a positive association with physical environment (0.948224), price (0.940249) and product quality $(0.955820)$. Physical environment is positively associated with price $(0.922528)$ and product quality $(0.929675)$. Price is also positively associated with product quality (0.939334).

In checking for multi-colinearity, the study observed that no two explanatory variables were perfectly correlated. This indicates the absence of multicolinearity problem in the model used for the analysis and justifies the use of the ordinary least square method. 
Table 4.3: Regression Analysis

\begin{tabular}{|c|c|c|c|c|}
\hline Variable & Coefficient & Std. Error & t-Statistic & Prob. \\
\hline $\mathrm{C}$ & 0.457244 & 1.354797 & 0.337500 & 0.7367 \\
\hline SQ & 0.078506 & 0.151771 & 0.517266 & 0.6066 \\
\hline $\mathrm{PE}$ & 0.364649 & 0.119716 & 3.045941 & 0.0033 \\
\hline PR & 0.263788 & 0.117252 & 2.249755 & 0.0276 \\
\hline PQ & 0.277713 & 0.134652 & 2.062454 & 0.0429 \\
\hline$\overline{R \text {-squared }}$ & 0.911354 & \multicolumn{2}{|c|}{ Mean dependent var } & 29.80000 \\
\hline Adjusted R-squared & 0.906289 & \multicolumn{2}{|c|}{ S.D. dependent var } & 22.60770 \\
\hline S.E. of regression & 6.920727 & \multicolumn{2}{|c|}{ Akaike info criterion } & 6.771259 \\
\hline Sum squared resid & 3352.752 & \multicolumn{2}{|c|}{ Schwarz criterion } & 6.925758 \\
\hline Log likelihood & -248.9222 & \multicolumn{2}{|c|}{ Hannan-Quinn criter. } & 6.832949 \\
\hline F-statistic & 179.9154 & \multirow{2}{*}{\multicolumn{2}{|c|}{ Durbin-Watson stat }} & 2.343713 \\
\hline Prob(F-statistic) & 0.000000 & & & \\
\hline
\end{tabular}

The R-squared which is the co-efficient of determination or measure of goodness of fit of the model, tests the explanatory power of the independent variables in any regression model. From our result, the R-squared (R2) is 91\% in the Model.

This showed that our model displayed a good fit because the R2 is closer to $100 \%$, these explanatory variables can impact up to $91 \%$ out of the expected $100 \%$, leaving the remaining $9 \%$ which would be accounted for by other variables outside the models as captured by the error term. The Fstatistics measures the overall significance of the explanatory parameters in the model, and it shows the appropriateness of the model used for the analysis while the probability value means that model is statistically significant and valid in explaining the outcome of the dependent variables. From table 4.3 above, the calculated value of the fstatistics is 179.9154 and its probabilities are 0.000000 which is less than 0.05 . We therefore accept and state that there is significance relationship between the variables. This means that the parameter estimates are statistically significant in explaining the relationship in the dependent variable.

The t-statistics helps in measuring the individuals' statistical significance of the parameters in the model from the result report. It is observed from table 4.3 above that physical environment (PE), price (PR) and product quality (PQ) were statistically significant at $5 \%$ with its values as $3.045941,2.249755$ and 2.062454 respectively. This implies that they have contributed significantly to customers' satisfaction (CS) at the 5\% level of significance.

Service quality (SQ) was statistically insignificant at $5 \%$ with its value as 0.517266 . This implies that it has contributed insignificantly to customers' satisfaction (CS) at the 5\% level of significance. Our model is free from the problem of autocorrelation because the Durbin-Watson value is 2.343713 which is approximated as 2 (that means, the absence of autocorrelation in the model used for the analysis).

The a'priori criteria are determined by the existing accounting theory and states the signs and magnitude of the variables from the result. Service quality (SQ), physical environment (PE), price (PR) and product quality (PQ) has positive signs and its values are $0.517266,3.045941,2.249755$ and 2.062454 respectively.

In the Model, this implies that increase in SQ, PE, PR and PQ increases the customers' satisfaction (CS) by $52 \%, 305 \%, 225 \%$ and $206 \%$ respectively, this conforms to our theoretical expectation.

\section{DISCUSSION OF RESULT AND FINDINGS}

The main objective of this study is to investigate the determinants of customers' satisfaction in the fast food industry in Anambra State of Nigeria.

Initially, the specific objective one was to ascertain the effect of service quality on customers' satisfaction in the fast food industry in Anambra State of Nigeria. Based on tested hypothesis one result on table 4.3 (t-statistic $=0.517266 ; \mathrm{p}$-value $=$ 0.6066 ). Since p-value 0.6066 is greater than 0.05 the stipulated significant level; we therefore reject the alternative and accept the null hypothesis.

The decision is that service quality has positive and insignificant influence on customers' satisfaction in the fast food industry in Anambra State of Nigeria. This implies that service quality has positive insignificant influence on customers' satisfaction in the fast food sub-sector in Anambra State of Nigeria. This is in line with the findings of Manjunath and Reginald (2016) and was against the findings of Sabir, Ghafoor, Hafeez, Akhtar and Rehman (2014) who found that service quality has positive significant influence on customers' satisfaction.

Secondly, the specific objective two aimed to determine the effect of physical environment on customers' satisfaction in the fast food industry in Anambra State of Nigeria. Based on tested hypothesis two result on table 4.3 (t-statistic = $3.045941 ; p$-value $=0.0033$ ). Since $p$-value 0.0033 is less than 0.05 the stipulated significant level; we therefore reject the null and accept the alternative hypothesis.

The decision is that physical environment has positive and significant influence on customers' 
satisfaction in the fast food industry in Anambra State of Nigeria. This implies that physical environment has positive significant influence on customers' satisfaction in the fast food industry in Anambra State of Nigeria. This is in line with the findings of Sabir, Ghafoor, Hafeez, Akhtar and Rehman (2014) that found that physical environment has positive significant influence on customers' satisfaction in the fast food industry, and were against the findings of Manjunath and Reginald (2016).

Thirdly, the specific objective three sought to examine the effect of price on customers' satisfaction in the fast food industry in Anambra State of Nigeria. Based on tested hypothesis three result on table 4.3 (t-statistic $=2.249755$; $\mathrm{p}$-value $=$ 0.0276 ). Since p-value 0.0276 is less than 0.05 the stipulated significant level; we therefore reject the null and accept the alternative hypothesis.

The decision is that price has positive and significant influence on customers' satisfaction in the fast food industry in Anambra State of Nigeria. This implies that price has positive significant influence on customers' satisfaction in the fast food industry in Anambra State of Nigeria. This is in line with the findings of Manjunath and Reginald (2016) and was against the findings of Sabir, Ghafoor, Hafeez, Akhtar and Rehman (2014) who found that price is negative and has insignificant influence on customers' satisfaction in the fast food industry.

Fourthly, the specific objective four aimed to investigate the effect of product quality on customers' satisfaction in the eateries in Anambra State of Nigeria. Based on tested hypothesis two result on table 4.3 (t-statistic $=2.062454 ; \mathrm{p}$-value $=$ $0.0429)$. Since p-value 0.0429 is less than 0.05 the stipulated significant level; we therefore reject the null and accept the alternative hypothesis.

The decision is that product quality has positive and significant influence on customers' satisfaction in the fast food industry in Anambra State of Nigeria. This implies that product quality has positive significant influence on customers' satisfaction in the eateries in Anambra State of Nigeria. This is in line with the findings of Manjunath and Reginald (2016) whose study conclusionshowed that product quality has positive significant influence on customers' satisfaction in the fast food sub-sector.

\section{CONCLUSION AND \\ RECOMMENDATIONS}

Based on the findings, the study concludes that physical environment (PE), price (PR) and product quality (PQ) are significantly instrumental in influencing customers' satisfaction in the fast food industry in Anambra State of Nigeria. The study concludes that the product quality (SQ) has less significant influence on customers' satisfaction in the fast food industry in Anambra State of Nigeria.

Thus, managers of fast food industry should pay attention to these variables in their decisions when making marketing strategies since they play a vital role in the market field, and to measure the customer satisfaction these variables such as physical environment, price, product quality and even quality in service of the restaurants should be considered by the manager since they have positive effect on the customers' satisfaction in the fast food industry in Anambra State of Nigeria.

\section{REFERENCES}

1. Adiele K.C. \& Opara, B.C. (2014).Analysis of Corporate Identity on Customer Patronage of Banks in Nigeria. International Review of Management and Business Research, 3(4), $1809-1818$.

2. Adiele, K.C., Miebaka, D.G. and Ezirim, A.C. (2015). Physical Evidence and Customer Patronage: An Empirical Study of Nigeria Banking Sector. British Journal of Economics, Management \& Trade, 7(3): 188-199.

3. Agbemabiese, G.C., Patrick, A.A. and Adu, A.G. (2015). Effect of Customers' Satisfaction of Service Delivery on Customers' Retention of Tigo Telecommunication Network: A Case of Abokobi-Madina Locality. The International Journal of Business \& Management.3(1).

4. Ahmad A. Al-Tit (2015). The Effect of Service and Food Quality on Customer Satisfaction and Customer Retention.Published by Canadian Centre of Science and Education. 11, (23)

5. Anifowose, O.L. \& Olaleye, O. O. (2016).Assessment of Customers' Satisfaction on Service Quality of Fast Food Restaurant in Akure Metropolis. Journal of Management and Corporate Governance, 8(1), $51-63$.

6. Ayse Ozfer Ozcelik, (1988). An Evaluation of Fast-Food Preferences According to Gender. Humanity \& Social Sciences Journal, 2 (1) 43-50

7. Barkema, A., Drabenstott, M., \& Welch, K. (1991): The quiet revolution in the US food market. Economic Review (May/June), 25-41.

8. Bell J, Gilbert D, and Lockwood A. (1997). Service quality in food retailing operations: a critical incident analysis. The International Review of Retail, Distribution and Consumer Research 7: 405-423.

9. Bitner, M.J. (1990). Evaluating Service Encounters: The Effects of Physical Surrounding and Employee Response, Journal of Marketing, 54(2), 69-82.

10. Customer Satisfaction in Fast Food Industry: A Case Study of Mysore. International Journal of Research in Finance and Marketing, 6(5), $72-78$.

11. Deng, Z., Lu, Y, Wei, K.K., Zhang, J. (2009). Understanding customer satisfaction and loyalty: An empirical study of mobile instant messages in China, International Journal of Information Management, 30, 289-300.

12. Dipeolu A., Adewuyi, S., Ayinla, M. and Bakare, A. (2014).Customer Satisfaction in Fast Food Restaurants in Ibadan Metropolis. Journal of Marketing and Consumer Research, 5, $12-19$

13. Dominici G, and Guzzo R (2010) Customer satisfaction in the hotel industry: a case study from Sicily. Journal of Marketing and Consumer Research, 5, 12 - 19.

14. Eshghi, A., Haughton, D., and Topi, H., (2008). Determinants of customer loyalty in the wireless telecommunications industry, Telecommunications policy, 31(2), 93-106.

15. Fornell C, Johnson MD, Anderson EW, Cha J, and Bryant BE (1996) The American customer satisfaction index: 
nature, purpose, and findings. The Journal of Marketing. 4(5).

16. Ghobadian A, Speller S, Jones M (1994) Service quality: concepts and models. International Journal of Quality \& Reliability Management 11:43-66.

17. Gronroos. (1984). A service quality model and its marketing implications. Journal of the Academy of Marketing Science, 24 (Winter), 36-44.

18. Gustafsson, A., Johnson, M.D., and Roos, I. (2005), "The Effects of Customer Satisfaction, Relationship Commitment Dimensions, and Triggers on Customer Retention”, Journal of Marketing, 6(9), 210-218.

19. Han, K.R.H (2009) Influence of the Quality of Food, Service, and Physical Environment on Customer Satisfaction and Behavioral Intention in Quick-Casual Restaurants: Moderating Role of Perceived Price.

20. Hernon P, Nitecki DA, Altman E. (1999) Service quality and customer satisfaction: An assessment and future directions. The Journal of Academic Librarianship 25: 9-17.

21. Jenet Manyi Agbor (2011). The Relationship between Customer Satisfaction and Service Quality: A Study of Three Service Sectors in Umea.

22. Johns N, and Howard A. (1998) Customer expectations versus perceptions of service performance in the foodservice industry. International Journal of Service Industry Management 9: 248-265.

23. Khan, S. (2012). Determinants of customer satisfaction in fast food industry. International Journal of Management and Strategy , 1(3).

24. Khan, S., Hussain, S.M. and Yaqoob, F. (2013) Determinants of Customer Satisfaction in Fast Food Industry A Study of Fast Food Restaurants Peshawar Pakistan. Studiacommercialia Bratislavensia, 6(21), 56 - 65.

25. Kotler, P. (2012). Principles of marketing, 14th Edition. Pearson Education.

26. Kotler, P. and Keller K. (2009), Marketing Management . New Jersey: Prentice Hall Kumar, M. (2012). Determining the Relative Importance of Critical Factors in Delivering Service Quality of Banks; an Application of Dominance Analysis in SERVQUAL Model, Managing Service Quality, 19(2), 211-228.

27. Kurniawan, B. (2010). Factors affecting customer satisfaction in purchase Decision on ticket online. a case study in air asia.

28. Lim, H. (2010). Understanding American customer perceptions on Japanese food and services in the U.S. UNLV Theses / Dissertations / Professional Papers / Capstones.

29. Lin, Y.C. and Wu, H.C.J. (2011). An Empirical Analysis of Synthesizing the Effects of Service Quality, Perceived Value, Corporate Image and Customer Satisfaction on Behavioral Intentions in the Transport Industry: $A$ case of Taiwan High-Speed Rail. Innovative Marketing, 7(3), 83-100.

30. Manjunath, S. J. and Reginald, S. (2016). Customer Satisfaction in Fast Food Industry a case study of Mysore.
International Journal of Research in Finance and marketing. 6(5), 72-78.

31. Oliver, R.L., \& DeSarbo, W.S., (1988).Response Determinants in Satisfaction Judgments. The Journal of Consumer Research. 14(4), 495-507.

32. Oliver, R.L. (1981). Measurement and Evaluation of Satisfaction Processes in Retail Settings. Journal of Retailing. 57(3), 25-48.

33. Parasuraman, A., Zeitham, A. V. \& Berry, L.L. (1988). SERVQUAL: A multiple-item scale for measuring consumer perceptions of service quality. Journal of Retailing, 64 (1): 12-40.

34. Rana M.W, Lodhi R. N, Butt G. R., Dar W. U. (2017) How Determinants of Customer Satisfaction are Affecting the Brand Image and Behavioral Intention in Fast Food Industry of Pakistan? Journal of Tourism Hospitality. 6: 316.doi: 10.4172/2167-0269.1000316

35. Sabir, R.I., Ghafoor, O., Hafeez, I., Akhtar, N. and Rehman, A. (2014). Factors Affecting Customers Satisfaction in Restaurants Industry in Pakistan. International Review of Management and Business Research, 3 (2), $869-876$.

36. Schlesinger L.A, and Heskett J.L. (1991). Breaking the cycle of failure in services. MIT Sloan Management Review 32: 17.

37. Skindaras, R.V. (2009). The Relationship between Price and Loyalty in Services Industry. ISSN 1392-2785 Inzinerine Ekonomika-Engineering Economics Commerce of engineering decisions, 3.

38. Soriano R. D (2002). Customers' expectations factors in restaurants: The situation in Spain. International Journal of Quality \&Reliability Management 19: 1055-1067.

39. Spreng, R.A., and Mackoy, R.D. (1996).An Empirical Examination of a Model of Perceived Service Quality and Satisfaction. Journal of Retailing, 72(2), 201-214.

40. Takeuchi, H. a. J.A.Q. (1983). Quality Is More Than Making a Good Product. Harvard Business Review, 61, 139-145.

41. Turel, O., and Serenko, A. (2006). Satisfaction with mobile services in Canada: An empirical investigation. Telecommunication policy, 30, (5, 6), Pages 314-331.

42. Zairi, M. (2000).Managing Customer Dissatisfaction through Effective Complaint Management Systems. The TQM Magazine, 12 (5), 331-335.

43. Zeithaml VA, Berry LL, Parasuraman A (1996).The behavioral consequences of service quality. The Journal of Marketing. 49 (Fall) $41-50$.

44. Zeithaml, P. A. (1985). A conceptual model of service quality and its implication for future research. Journal of Marketing Research, 49 (Fall) 41-50. 